\title{
ТАТЬЯНА КРАСИЛЬНИКОВА
}

0000-0002-1108-2641

Национальный исследовательский университет

«Высшая школа экономики»

Факультет гуманитарных наук

Школа филологии

105066 Москва

ул. Старая Басманная, д. 21/4

tanyakrasilnikova96@mail.ru

\section{«ВЫ ЛОСЕВ? НЕТ, СКОРЕЕ, ЛИФШИЦ»: АВТОРСКАЯ САМОНОМИНАЦИЯ В ПОЭЗИИ ЛЬВА ЛОСЕВА}

\section{'YOU'RE LOSEFF?' 'NO, LIFSHITS AM I': SELF-NAMING IN LEV LOSEFF'S POETRY}

Настоящая статья - часть исследования под названием Лирический персонаж в поэзии Льва Лосева: образ, имя, отражение, в фокусе которого три аспекта: во-первых, категория «лирического персонажа», предложенная для описания образа автора в довольно большом корпусе стихотворений Лосева; во-вторых, проблема самономинации поэта; в-третьих, мотив отражения лирического персонажа в зеркале. В реальной жизни у Льва Лосева было несколько имен и фамилий, и совсем неудивительно, что такое разнообразие воплотилось и в творчестве поэта. Предложенный ракурс помогает определить, чем объединены многие «ключевые» стихотворения Льва Лосева, приблизиться к пониманию его поэтики и одновременно с этим приоткрыть новые дискуссионные области.

Ключевые слова: авторская самономинация, лирический персонаж, интерпретация поэтического текста, Лев Лосев.

The article is a part of a study titled "The Lyrical Character in Lev Loseff's Poetry: Image, Name and Reflection", concerned with three aspects: firstly, the category of "the lyrical character", proposed to describe the author's image in a substantial corpus of Loseff's poems; secondly, the issue of self-naming; thirdly, the motive of the subject's reflection in a mirror. In real life Loseff had a number of names and surnames and it is not surprising that their multiplicity found its way into his poetry. The perspective adopted in the article enables a better understanding of Loseff's poetics as well as opens new areas for discussion.

Keywords: author's self-naming, "the lyrical character", poetry interpretation. 
Лиф поправляет лениво рыбачка. Shit-c на песке оставляет собачка.

Лев Лосев ${ }^{1}$

Поэта, имени которого посвящена настоящая статья, в детстве по документам звали Лев Владимирович Лифшиц. Имя «Лев» придумал, как рассказывает автор книги Меандр, художник Борис Семенов:

Кстати сказать, и мое имя, Лев, это Боря придумал. По маминым рассказам, они с отцом сверх всяких сроков затянули, все не могли решить, как назвать новорожденного. Наконец Боря посоветовал назвать в честь маминого любимого старшего брата, который, будучи студентом Военно-медицинской академии, умер неожиданно от стрептококковой инфекции. «Лев, Левушка - прекрасное имя». Пошли в загс и записали меня Львом, и с тех пор ни разу в жизни ни мать, ни отец, ни Боря, никто из близких меня этим именем не звал, а только - Леша, Лешка, Лешенька².

Уже после, когда «Лёша Лифшиц» начал работать в детском журнале «Костёр», его отец, известный советский поэт Владимир Лифшиц, предложил сыну взять псевдоним, дабы избежать двух «Лифшицев» в одной сфере детской литературы. На реплику Лёши «Вот ты и придумай» отец «с бухты-барахты» сказал «Лосев!» . Интересно, что сочетание «Лев Лосев» закрепилось не сразу. Так, например, на страницах «Костра» под стихами и прозой стоит подпись «Алексей Лосев» или «А. Лосев». Александр Генис в разговоре с Соломоном Волковым вспоминает о путанице, которая происходила из-за неясной ситуации с именем:

[...] он одно время подписывал тексты «Алексей Лившиц», а стихи - «Лев Лосев». И в «Новый американец», где мы его тогда печатали, прислали письмо и сказали: «Сколько можно? То ли он Алексей, то ли он Лев!?». И Лосев прислал в ответ письмо, где сказал, что «я извиняюсь, что иногда Алексей, иногда Лев, но это не так страшно, потому что был прецедент, был Толстой» $[\ldots]^{4}$.

На страницах «Костра» можно встретить и шутливую подпись «Л. Осев». Уже в американском паспорте имя поэта выглядело так: Lev Lifschitz Loseff, а в кратком варианте - Lev L. Loseff.

\footnotetext{
${ }^{1}$ Л. В. Лосев, Стихи, Санкт-Петербург: Издательство Ивана Лимбаха 2012, с. 40.

2 Л. В. Лосев, Меандр: Мемуарная проза, Москва: Новое издательство 2010, с. 157.

${ }^{3}$ Л. В. Лосев, Стихи, Санкт-Петербург: Издательство Ивана Лимбаха 2012, с. 14.

${ }^{4}$ Диалог на Бродвее. Александр Генис и Соломон Волков, [электронный ресурс] http:// www.svoboda.org/a/24618746.html [29.08.2018].
} 
Столь необычная ситуация, связанная с необходимостью смены фамилии и с наличием двух вариантов имени, оставила глубокий след в поэзии Льва Лосева. На протяжении почти всего творчества, начиная со сборника Памяти водки («гранатомётчик Лёва Лившиц» $)^{5}$ и заканчивая Говорящим попугаем («...имя новое определилось - Лось» ${ }^{6}$ ), поэт варьирует имена, прозвища, пытается подобрать наиболее подходящее сочетание имени и фамилии, иронизирует над самономинацией и рефлексирует над таким внушительным количеством путей называния себя ${ }^{7}$. Вполне очевидно, что останавливаться подробно на каждом стихотворении, где так или иначе присутствует имя поэта, не представляется сколь-нибудь необходимым: в большинстве примеров сама манера называния персонажа не играет весомой роли в общей картине. О многих таких стихотворениях будет упомянуто вскользь.

Прежде чем начать анализ стихотворений, хотелось бы в самом сокращенном виде пояснить, что я понимаю под термином «лирический персонаж» ${ }^{8}$ применительно к поэзии Лосева. Большинство уже ставших хрестоматийными стихотворений Льва Лосева хочется назвать «автобиографическими»: их тематика - жизненный опыт автора, фрагмент из жизни, вопросы к своей судьбе, попытка самоопределения и др. Утверждение, что реальный автор не равен образу автора в тексте, казалось бы, заведомо отвечает на все предполагаемые вопросы. Тем не менее, во время подробного знакомства со стихами читатель неизбежно сталкивается с парадоксальной ситуацией: в наиболее «автобиографических» стихотворениях (но ни в коем случае не во всём корпусе стихов поэта), где речь идет именно о чем-то из жизни Льва Лосева, образ автора в тексте в высокой степени одновременно равен и не равен «создателю» реальному. В таких случаях самым подходящим понятием кажется «лирический персонаж», то есть другой по отношению к автору 9 .

\footnotetext{
${ }^{5}$ Л. В. Лосев, Стихи..., с. 21.
}

${ }^{6}$ Там же, с. 566.

${ }^{7}$ Упоминание в стихотворении имени поэта закреплено в литературоведении за термином «сфрагида». См.: А. П. Квятковский, Поэтический словарь, Москва: Советская Энциклопедия 1966, с. 292-293. Позволю себе, однако, не злоупотреблять этим понятием.

${ }^{8}$ Наша статья Лирический персонаж в поэзии Льва Лосева находится в печати.

${ }^{9} \mathrm{C}$ опорой на идеи М. М. Бахтина об автобиографическом авторе в прозаических текстах и идеи Б. О. Кормана о ролевом герое; только если герой ролевой лирики находится на стыке драмы и лирики, то под лирическим персонажем подразумевается субъект лирики (в широком смысле), на которого автор смотрит как на другого, не равного себе, и описывает скорее как эпического персонажа - находящегося на стыке эпоса и лирики. Ср.: Б. О. Корман, Лирика Некрасова, Ижевск 1978, с. 390; М. М. Бахтин, Эстетика словесного творчества, сост. С. Г. Бочаров; текст подгот. Г. С. Бернштейн и Л. В. Дерюгина; примеч. С. С. Аверинцева и С. Г. Бочарова, Москва: Искусство 1979, с. 423 (Из истории советской эстетики и теории искусства). 
Дабы упорядочить весь массив отобранных текстов и построить удобную для анализа систему координат, выделим пунктиром несколько основных векторов:

1. Стихотворения, в которых упоминаются только имя или только фамилия: Он говорил: «А это базилик», Норковый ручей, De profundis; Повстречался мне философ, Нет, Игра слов с пятном света.

2. Стихотворения, в которых упоминаются имя и фамилия, имя и отчество или инициалы: Poта Эрота, ЛЕВЛОСЕВ, Pro Domo Sua, Один день Льва Владимировича, Сказка № 1, РУЖЬЁ (Петербургская поэмка).

3. Стихотворения, в которых автор рефлексирует над «бестиарной» составляющей своего имени: Инструкиия рисовальщику гербов, В Помneе, «Этот возраст преклонный на деле столик...», Torvaianica.

В кругу друзей и родственников Лосева называли Лёшей. Именно такой вариант выбран в качестве «семейного» имени для стихотворения Норковый ручей, в котором двумя главными персонажами являются муж и жена, Лёша и Нина ${ }^{10}$. В стихотворениях Он говорил: «A это базилик» и De profundis по-разному показан разговор за столом. В них собеседник обращается к поэту только по имени: «Он по-простому звал меня - Алеха. / «Давай еще, по-русски, под пейзаж»»» ${ }^{11}$ или: «Трактирщик говорит: «Ну, Лёш, / что ты, Лёша, воду мутишь»?» ${ }^{12}$. Такой способ номинации соответствует обстановке - она либо семейная, либо расслабленно-застольная. В противоположность ситуациям, когда лирическому персонажу обращаются только по имени, в некоторых текстах упоминается лишь фамилия (точнее, фамилии). Рассмотрим некоторые примеры.

В стихотворении «Повстречался мне философ...» попытка философа идентифицировать личность поэта предполагает обращение именно по фамилии:

Повстречался мне философ

в круговерти бытия.

Он спросил меня: «Вы - Лосев?»

Я ответил, что я я.

И тотчас засомневался:

я ли я или не я.

А философ рассмеялся, разлагаясь и гния ${ }^{13}$.

\footnotetext{
${ }^{10}$ Подробнее об этом стихотворении в статье: Т. А. Красильникова, «Норковыгй ручей» Льва Лосева: сквозь призму Фроста, «Новый филологический вестник» 2018, № 44, с. 210-222.

${ }^{11}$ Л. В. Лосев, Стихи..., с. 17.

${ }^{12}$ Там же, с. 223.

${ }^{13}$ Там же, с. 354.
} 
Сомнения героя, конечно, обусловлены онтологическими проблемами, однако, наличие большого количества способов самономинации также сказывается на невозможности сразу ответить на подобный вопрос. Так, на в точности такую же реплику («Вы Лосев?») в другом стихотворении лирический персонаж отвечает иначе: «Вы Лосев? Нет, скорее Лифшиц, / мудак, влюблявшийся в отличниц, / в очаровательных зануд / с чернильным пятнышком вот тут» ${ }^{14}$. Уже в одном этом исправлении - и возвращение в детство, и отрицание взросления, и воспоминание о нелепости и неуклюжести подростка, и привычное обращение к школьнику по фамилии. Такое же, как и, например, в Игре слов с пятном света:

Как в школе.

«Спорим, что не сможешь сказать «дапис» десять раз подряд и не сбиться».

Как дурак доказываю, что могу.

«Александра Марковна, а Лифшиц ругается! ${ }^{15}$

Этот закрепленный в узусе способ коммуникации является здесь индикатором не слишком уважительного обращения друг к другу - и со стороны учеников, и со стороны учителей советской школы - особенно если учитывать воспоминания Лосева о своих школьных годах ${ }^{16}$.

Есть случаи, когда в тексте употребляется полное имя лирического персонажа. В стихотворении Роте Эрота авторское определение лирического персонажа - «гранатомётчик Лёва Лифшиц», соответствующее духу военных сборов (более «пацанское» и развязное «Лёва»). В стихотворении Pro Domo Sua фольклорный песенный ритм задает и игровой вариант имени: «Ломкий лёд галиматьи. / Тонкий звон со дна бадьи. / Выплывают ледяные / Лёшки Лосева ладьи» ${ }^{17}$.

Совершенно другой пример представляет собой стихотворение Левлосев. Лирический персонаж здесь одновременно и обладает, и не обладает одинаковым с реальным автором именем:

Левлосев не поэт, не кифаред.

Он маринист, он велимировед,

бродскист в очках и с реденькой бородкой,

\footnotetext{
${ }^{14}$ Там же, с. 359 .

${ }^{15}$ Там же, с. 436.

${ }^{16}$ Вот лишь один пример: «В четвертый и пятый класс я ходил в 311-ю школу на Малодетскосельском. Учителя вспоминаются гоголевскими монстрами. Учитель литературы Александр Васильевич так нас ненавидел, что однажды ударил расшалившегося мальчика стулом по голове...». См.: Л. В. Лосев, Меандр..., с. 196.

${ }^{17}$ Л. В. Лосев, Стихи..., с. 308.
} 
он осиполог с сиплой глоткой, он пахнет водкой, он порет бред.

Левлосевлосевлосевлосевононононононононон иуда ${ }^{18}$.

Слитно написанные имя и фамилия, они превращены в одно слово, некий объект, подлежащий описанию. Автор имеет в виду и себя, и несебя, а другого, отдельного от него «Львалосева», которого можно поместить в текст, и, над которым можно произвести лингвистическую операцию, «склеив» имя и фамилию в единое целое. Начало второй строфы - это превращение имени в гул, «звон», смешение разных голосов толпы, постоянно и бездумно твердящей о предательстве и о чужих грехах. Похожую роль - называние своего лирического персонажа - играет имя в заглавии стихотворения Один день Льва Владимировича ${ }^{19}$, которое после этого в тексте не упоминается (всё стихотворение написано от первого лица). Взяв за образец заглавия повесть А. С. Солженицына Один день Ивана Денисовича, Лосев делает из образа себя лирического персонажа и наделяет его заведомо литературным именем - помещая в литературный контекст.

В стихотворении Сказка № $1^{20}$ вместо имени персонажа упоминаются лишь инициалы - «Л. Л.». Ср.:

Гуляя по Кудыкиной горе,

вырезывая в липовой коре:

«Здесь был Л. Л.», «Здесь был Л. Л.», «Здесь был Л. ...»

Здесь был, да сплыл. Здесь был, да был таков.

Хоть пробовал отмычкой сто замков,

хоть воду мертвую на землю вылил.

Оставление лишь первых согласных имени и фамилии (причем не важно, Лёва, Лёша или Лев, Лифшиц или Лосев) обусловлено ситуацией: их поэт (или в данном случае протагонист волшебной сказки) вырезает на коре дерева, используя типичную для этого фразу «Здесь был...», а фраза, в свою очередь, отзывается эхом в лесу. Однако во второй строфе такой способ номинации закрепляется в сознании и выходит за рамки заданной ситуации: «Теперь с сырой земли глядит оно, / как глаз Л. Л., прищурившись и мимо» ${ }^{21}$.

\footnotetext{
${ }^{18}$ Там же, с. 255.

${ }^{19}$ Там же, с. 165 .

${ }^{20}$ Там же, с. 543.

${ }^{21}$ Там же.
} 
Американский «паспортный» вариант написания имени и фамилии, 'Lev Loseff', появляется в приложении к Петербургской поэмке «РУЖЬЁ», написанной на отвергнутый Гоголем сюжет о чиновнике, который копил деньги не на шинель, а на оружие. В приложении к «поэмке» лирический персонаж Льва Лосева трогает «монумент» Гоголя, за что подвергается упрекам со стороны иностранца. Гоголь этого иностранца прогоняет и обращается к Loseff'y:

\author{
Что по глупости ль, по пьянке ль \\ казачки́ не натворят... \\ в рай зато попал ты, Янкель, \\ а они в аду горят». \\ Я ответил: «Я не Янкель, \\ я Lev Loseff , здесь не рай, \\ гений - никогда не ангел. \\ ты не ангел, Николай ${ }^{22}$.
}

Владислав Кривонос, составивший подробный комментарий к лосевской вариации гоголевского сюжета, так анализирует фрагмент:

\begin{abstract}
Гоголь принимает бранящего его чужака за одного из своих персонажей, Янкеля, пострадавшего от казачков, имя которого служит еще и обозначением еврея. Однако Lev Loseff, отказываясь от навязанного ему литературного амплуа и обращаясь к Гоголю как к товарищу (предлагая ему покурить), развивает еврейскую тему так, что анекдотическая история неожиданно вписывается в карнавально-маскарадную атмосферу праздника Пурим, где вполне уместными оказываются и авторские благоглупости ${ }^{23}$.
\end{abstract}

Помимо уже отмеченного исследователем предпочтения своего имени другому, необходимо также добавить, что лирический персонаж предпочитает именно своё американское имя - вариант, прописанный в его новом паспорте, а не «еврейскую» фамилию «Лифшиц» и не «русскую» фамилию «Лосев»; неслучайно через две строфы «сивая кобыла» «залает blah, blah, blah» именно по-английски.

Наличие в придуманном псевдониме корней «лев» и «лось» не могло не породить рефлексии над «бестиарной составляющей» такого варианта самономинации. В предуведомлении к книге стихов Чудесный десант Лев Лосев вспоминает рисунок, созданный Михаилом Ерёминым сразу после

\footnotetext{
${ }^{22}$ Там же, с. 470.

${ }^{23}$ В. Ш. Кривонос, Проблема смысловой границы в анекдоте (Лев Лосев, Гоголь и история о бедном чиновнике), [в:] Литературоведческий сборник. Вып. 37-38. Так как же сделана «Шинель» Н. В. Гоголя?, Донецк 2009, с. 184.
} 
его переименования: на нем изображено животное с мордой льва и телом лося. В этой картинке Лосев сразу же прочитал отсылку к фрагменту из хлебниковских Трущฺоб:

Оленю нету, нет спасенья.

Но вдруг у него показались грива

И острый львиный коготь,

И беззаботно и игриво

Он показал искусство трогать ${ }^{24}$.

Сочетание двух разных животных, анаграммирование слова «лев» внутри фамилии «лосев» не могли не отразиться на творчестве поэта.

Инструкиия рисовальщику гербов ${ }^{25}$ представляет собой блазонирование, описывающее три возможных варианта герба Льва Лосева. Проанализирую подробно два последних, так как именно в них упоминаются имена:

2-ой вариант

На постаменте в виде опрокинутой стопки

две большие скобки,

к коим стоят как бы привалившись:

справа - лось сохатый,

слева - лев пархатый;

в скобках вставший на дыбы Лифшиц;

изо рта извивается эзопов язык,

из горла вырывается зык,

хвост прищемлен, на голове лежит корона в виде кепки,

фон: лесорубы рубят лес - в Лифшица летят щепки,

в лапах и копытах путается гвардейская лента

с надписью:

ЗВЕРЕЙ НЕ КОРМИТЬ

3-ий вариант (поскромнее)

Земной шар

в венце из хлебных колосьев,

перевитых лентой;

на поясках

красивым курсивом надпись:

ЛЕВ ЛОСЕВ

на 15-ти языках.

${ }^{24}$ В. Хлебников, [электронный ресурс] http://rvb.ru/hlebnikov/tekst/001stihi/033.htm [29.08.2018].

${ }^{25}$ Л. В. Лосев, Стихи..., с. 121. 
Второй вариант герба предполагает изображение двух зверей, льва и лося, и лирического персонажа со старой фамилией - Лифшиц. Эзопов язык, предмет главного исследования Льва Лосева, здесь материализуется и становится частью тела. Самая последняя строка - это, вероятно, советская реалия, привычная для зоопарка надпись «Зверей не кормить», которая теперь проецируется на лирического персонажа. Примечательна схожесть этого герба с гербом Монтефьоре в Иерусалиме, на которую указывает Юрий Колкер в одном из писем к Лосеву:

Знаете ли Вы, что Ваши стихи о гербе Льва Лосева [«справа лось сохатый, слева Лев пархатый...»] почти в точности описывают красующийся в центре Иерусалима герб известного благотворителя прошлого века Моше Монтефьоре? В нем - справа лось сохатый, слева - лев пархатый, а посредине щит с надписью םילשורי (Иерусалим), и еще кое-что ${ }^{26}$.

К сожалению, это замечание осталось не прокомментированным самим автором. Третий вариант пародирует государственный герб СССР, только вместо надписи на пятнадцати языках «Пролетарии всех стран, соединяйтесь!» - «красивым курсивом» ЛЕВ ЛОСЕВ. В стихотворении смешиваются несколько культур: в первом варианте это остатки древних цивилизаций (верблюд, нимфа, часть латинского афоризма "Verba volant, scripta manent"), во втором - еврейская культура с гербом в Иерусалиме и еврейской фамилией Лифшиц, проникающая в советский мир (гвардейская лента и надпись в советском зоопарке); а в третьем варианте герба - культура СССР.

В стихотворениях $B$ Помпее и «Этот возраст преклонный на деле столик» лирический персонаж принимает образ льва. Первое, с эпиграфом из Умирающего гладиатора М. Ю. Лермонтова, рассказывает о древнеримской смертной казни damnatio ad bestias («предание зверям»), и в данном контексте это, очевидно, казнь ранних христиан в Римской империи: «По макам ветер пробегает, / а страх мне спину прогибает, / и, первого святого съев, / я думаю: зачем я Лев?» ${ }^{27}$. Неслучайно конец стихотворения - последние две обособленные строки - так напоминает финал поэмы Блока Двенадиать:

Я озираюсь воровато, но мне с арены нет возврата, и вызывает мой испуг

${ }^{26}$ Ю. Колкер, Не только о Бродском. Юрий Колкер и Лев Лосев. Переписка 1985-88 годов, «Новый Берег» 2010, № 30, [электронный ресурс] http://magazines.russ.ru/bereg/2010/30/ br18.html [27.11.2018].

${ }^{27}$ Л. В. Лосев, Стихи..., с. 303. 
злорадство в римском господине

с дурманом черным в середине,

с кровавым венчиком вокруг ${ }^{28}$.

В центре композиции, как и у Блока - фигура человека, голова которого обрамлена венцом, только если в хрестоматийной поэме «венчик» белый, то здесь - «кровавый», и если у Блока это Исус Христос, то у Лосева - «римский господин», излучающий злорадство в противовес христианской покорности. Нельзя забывать и о том, что в христианской культуре за фигурой льва стоит Иисус Христос - отсюда сочетание хищника и жертвы в одном поэтическом образе.

Во втором стихотворении персонаж, пытающийся подобрать себе один из ста предполагаемых ликов, в определенный момент начинает предсказывать, что о нем будут говорить после смерти:

\footnotetext{
Или так: с чердака колокольня видна, а над ней облака и птицы видны.

Тишина, лишь в горсти у меня скрипит заколдованное золотое перо, и когда обнаружат мой манускрипт, все разлюбят зло и полюбят добро. «Этот старый лев нас учил добру»,скажут люди...29.
}

В отличие от предыдущего текста, здесь слово «лев» начинается со строчной буквы. Бестиарный образ в этом стихотворении связан с представлением о льве как о мудром «царе зверей», который может проповедовать добро. Получается, имя «Лев» в двух стихотворениях порождает разные варианты воплощения «львиной сущности»: в одном случае это зверь, невольно вынужденный участвовать в процессе казни в роли палача, а в другом - старый мудрый учитель, оставивший своим потомкам манускрипт. Возможна и перекличка со стихотворением польского поэта Збигнева Херберта Смерть Льва ${ }^{30}$, в котором запечатлен образ убегающего в лес зверя, преследуемого охотниками, и в то же время Льва Николаевича Толстого, преследуемого Софьей Андреевной. Здесь, как и в стихотворении «Этот возраст преклонный на деле столик», звучит мотив бегства, только если у Херберта это бегство от общества, то у Лосева - от самого себя.

\footnotetext{
${ }^{28}$ Там же.

${ }^{29}$ Там же, с. 525.

30 3. Херберт, Стихи, «Иностранная литература» 2001, № 5, [электронный ресурс] http:// magazines.russ.ru/inostran/2001/7/herbert.html [29.08.2018].
} 
На правомерность предположения о генетической связи текстов указывает соседство стихотворений «Из Збигнева Херберта» и «Этот возраст преклонный на деле столик» в сборнике Лосева Как я сказал.

Лирический сюжет стихотворения Torvaianica - второе рождение в пригороде Рима, после которого персонаж получает взамен своего старого имени Лев имя Лось:
Всё в мире оказалось повторимо.
Вторично мне родиться довелось в невзрачном дачном пригороде Рима, а имя новое определилось - Лось.
О, как свободно я бродил по Риму
без памяти, без денег, без стыда!
По-русски говорил, но только в рифму
и получалось здорово, когда
мне вдруг кивал из-за безносых статуй, из-за колонн, бредущих чередой, горбатый призрак, северный, сохатый, с еврейским профилем и жидкой бородой ${ }^{31}$.

Елена Погорелая в статье Диалоги с говорящии попугаем отмечает, что «царственный образ Льва исчезает, но эллинистический мир продолжает свидетельствовать о себе - бредущими чередою колоннами, бюстами, статуями» ${ }^{32}$. Синтез итальянского и русского «северного духа» она связывает с Пьяцией Матеи И. Бродского и в особенности с мандельштамовским стихотворением В разноголосице лирического хора. Интересно, что в этом тексте, в отличие от случаев с образом льва, образ лося и фигура автора не являются чем-то единым: «горбатый призрак» лишь иногда появляется на улицах города, отражая черты внешности лирического персонажа - «еврейский профиль» и «жидкую бороду». Такие метаморфозы, связанные с отказом от «львиной» части себя, приносят возможность растворения в пространстве, хаотичного передвижения и свободы действий.

Таким образом, проблема номинирования себя, отрефлексированная на уровне творчества, тесно связана с биографическими к этому предпосылками. Необходимость придумать себе псевдоним, дабы иметь возможность занять свою нишу в детской поэзии, впоследствии становится чем-то более серьезным и выходит за рамки игры (пусть и литературной):

${ }^{31}$ Л. В. Лосев, Стихи..., с. 566.

${ }^{32}$ Е. Погорелая, Диалоги с говорящим попугаем (о поэзии Льва Лосева), «Арион» 2010, № 4, [электронный pecypc] http://magazines.russ.ru/arion/2010/4/po19.html [29.08.2018]. 
фамилия «Лосев» превращается из псевдонима в настоящее паспортное имя, в «имя для жизни», для семьи, для друзей, для коллег по работе. Возникновение нового способа самономинации, причем на таком «ответственном» уровне, провоцирует появление лирического персонажа, будь то профессор, школьник, студент, солдат или даже лось или лев; и vice versa - появление лирического персонажа требует наделения его отличным от авторского именем. Этот взаимный процесс и стал частью настоящего исследования.

\section{References}

Bakhtin, Mikhail M. Estetika slovesnogo tvorchestva, ed. S. G. Bocharov. Moskva: Iskusstvo, 1979. (Iz istorii sovetskoi estetiki i teorii iskusstva).

Genis, Aleksandr, Volkov, Solomon. Dialog na Brodveye. http://www.svoboda.org/a/24618746.html.

Herbert, Zbigniew. "Stikhi”. Inostrannaya literatura, No. 5 (2001). http://magazines.russ.ru/ inostran/2001/7/herbert.html.

Khlebnikov, Velimir. http://rvb.ru/hlebnikov/tekst/001stihi/033.htm.

Kolker Yurii. "Ne tolko o Brodskom. Yurii Kolker i Losev Lev. Perepiska 1985-88 godov". Novyi Bereg, No. 30 (2010). http://magazines.russ.ru/bereg/2010/30/br18.html.

Korman, Boris O. Lirika Nekrasova. Izhevsk, 1978.

Krasilnikova, Tatyana A. "Norkovyi ruchei Lva Loseva: skvoz prizmu Frosta”. Novyi filologicheskii vestnik, No. 44 (2018): 210-222.

Krivonos, Vladislav Sh. Problema smyslovoi granitsy v anekdote (Lev Losev, Gogol i istoriya o bednom chinovnike). In: Literaturovedcheskii sbornik. No. 37-38. Tak kak zhe sdelana "Shinel” N. V. Gogolya?, Donetsk, 2009: 184.

Kvyatkovskii, Aleksandr P. Poeticheskii slovar. Moskva: Sovetskaya Entsiklopediya, 1966.

Losev, Lev. Meandr: Memuarnaya proza. Moskva: Novoe izdatelstvo, 2010.

Losev, Lev. Stikhi. Sankt-Peterburg: Izdatelstvo Ivana Limbakha, 2012.

Pogorelaya, Elena. "Dialogi s govoryashchim popugayem (o poezii Lva Loseva)". Arion, No. 4 (2010). http://magazines.russ.ru/arion/2010/4/po19.html. 